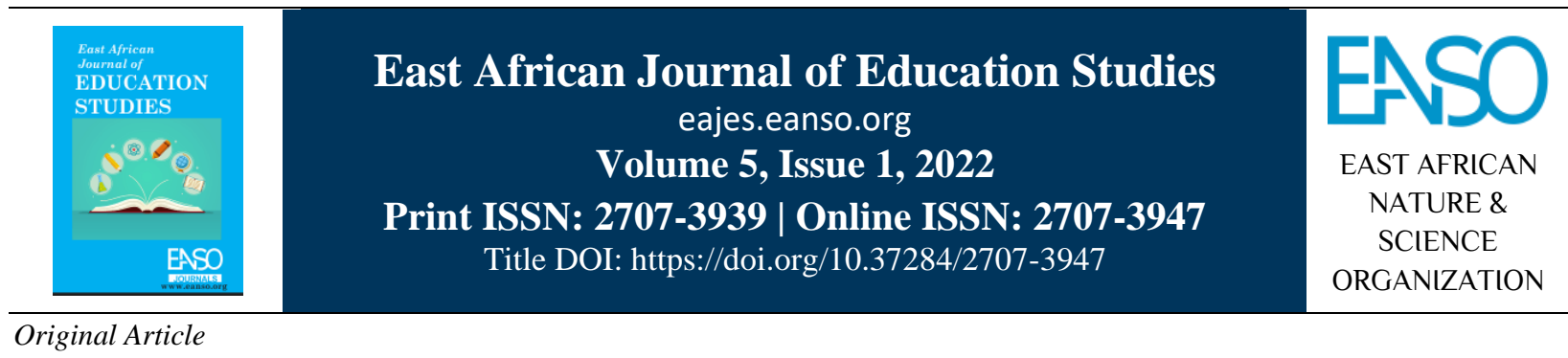

\title{
Academic Performance of Upgraded Extra-County Schools to National Status in Western Kenya Counties.
}

\author{
Violet Wekesa ${ }^{1 *}$ \& Prof. Kisilu Kitainge, $P h D^{1}$ \\ ${ }^{1}$ University of Eldoret, Kenya, P. O. Box 1125 - 30100, Eldoret. \\ * Author for Correspondence ORCID: https://orcid.org/0000-0002-7780-6980; Email: violetwekesa37@ gmail.com.
}

Article DOI: https://doi.org/10.37284/eajes.5.1.538

\section{Date Published: ABSTRACT}

28 January 2022 The success of students in secondary schools' systems is measured by their performance at the end of course examinations. In Kenya, the end

Keywords: of secondary school level of education examination is the Kenya

National School, Certificate of Secondary Education. This paper looks at the performance

Upgrading,

Academic,

Performance,

Extra County. of upgraded extra county schools to national status in western Kenya. The research adopted a descriptive research design; the target population were 295 teachers and eight school principals in upgraded Extra County Schools to the national level. Sample size calculation formula by role was used to get 170 teachers who were selected through a simple random sampling method, whereas all eight Principals were selected using purposive sampling. Data for this investigation were collected through teacher questionnaire, interview schedule for Principal and document analysis guide for secondary data. Analysis of data was done using frequencies, percentages, means, standard deviation and one sample statistics. Results showed that there was an $-18.7 \%$ change in KCSE performance from the year 2013 to 2018. Hence the upgrading of national schools in western Kenyan resulted in to drop in performance in all the upgraded schools under study. The study recommends that TSC should deploy more teachers in these schools, government to increase its support towards the upgrading of infrastructure in the upgraded schools in the region and the board of management to be proactive in planning for quality education provision in their schools.

\section{APA CITATION}

Wekesa, V., \& Kitainge, K. (2022). Academic Performance of Upgraded Extra-County Schools to National Status in Western Kenya Counties. East African Journal of Education Studies, 5(1), 26-34. https://doi.org/10.37284/eajes.5.1.538.

26 | This work is licensed under a Creative Commons Attribution 4.0 International License. 


\section{CHICAGO CITATION}

Wekesa, Violet, and Kisilu Kitainge. 2022. "Academic Performance of Upgraded Extra-County Schools to National Status in Western Kenya Counties”. East African Journal of Education Studies 5 (1), 26-34. https://doi.org/10.37284/eajes.5.1.538.

HARVARD CITATION

Wekesa, V. \& Kitainge, K. (2022) "Academic Performance of Upgraded Extra-County Schools to National Status in Western Kenya Counties”, East African Journal of Education Studies, 5(1), pp. 26-34. doi: 10.37284/eajes.5.1.538.

\section{IEEE CITATION}

V. Wekesa, \& K. Kitainge, "Academic Performance of Upgraded Extra-County Schools to National Status in Western Kenya Counties”, EAJES, vol. 5, no. 1, pp. 26-34, Jan. 2022.

\section{MLA CITATION}

Wekesa, Violet, and Kisilu Kitainge. "Academic Performance of Upgraded Extra-County Schools to National Status in Western Kenya Counties”. East African Journal of Education Studies, Vol. 5, no. 1, Jan. 2022, pp. 26-34, doi:10.37284/eajes.5.1.538.

\section{INTRODUCTION}

Education is considered as a vehicle for the national development of any country in addition to providing a pathway to students' future careers. The quality of education offered in secondary schools is normally measured by the performance of students in examinations. In Kenya, the final examinations of secondary school education are conducted at the end of the four-year course, Kenya Certificate of Secondary Education (KCSE). Students who perform well after secondary education are assumed to have received quality education which is key to country and individual development (Biama, 2014). Moreover, the performance of students in the KCSE examination is a determinant of the student enrolment in higher education that is colleges (for certificates and diplomas) and universities (for degrees) (Sidi et al., 2020). This has necessitated the government to improve the status of secondary education by opening new schools upgrading the existing ones while also expanding others to accommodate learners because of the $100 \%$ transitional policy by the Ministry of Education (Wekesa \& Kipkoech, 2021).

The Ministry of Education has categorised secondary schools into four levels; national, extra county, county and sub-county secondary schools (Odumbe et al., 2015). This study focuses on national schools, which are considered the elite group of schools in the Kenya secondary schools education tier (Gitogo, 2018). There has been high performance, fame, and prestige associated with national schools across the country for many years (Kithela, 2016). With the passage of the Kenya Constitution in 2010, there was a need for the country to ensure equality in the provision of education for all (primary and secondary) children in the country. This led the Ministry of Education in 2011 to elevate 30 more provincial schools to national status (total 48) in order to increase equity in access to secondary education. In the year 2013, the Ministry further upgraded 30 more extra county schools to national status to promote equity, national unity and cohesion, leading the total number of schools to 78 national schools from different counties in Kenya (Wekesa, Kipkoech \& Okemwa, 2021). The upgrading process did not stop there and 27 more schools were added making the country have a total number of such categories of schools at 105 by 2014. Before 2011, there were no national schools in the whole of western Kenya; therefore, from 2011-2014, a total of 8 extra county schools were upgraded to national status; these are Lugulu Girls, Bunyore Girls, Friends School Kamusinga, Butula Boys, Kakamega Boys, Butere Girls, Kolanya Girls and Chavakali Boys (Ngoko, 2019; Wekesa \& Kitainge, 2020).

Despite the upgrading of new extra county schools to the national level, past research has shown that some are struggling in performance. Kithela (2016) indicated that stakeholders were worried about the quality of education in these schools as they are set for massive intakes because of their upgrading. Siringi (2014) reported that some newly upgraded national schools had recorded poor performance in the 2012 KCSE examinations. Ten of those national schools could not even be ranked among the best top 100 district schools by the year 2013. Lucas and Mbiti (2014) observed that despite their reputations, research has shown little evidence of positive influence on academic performance for students 
who attended the newly upgraded schools, indicating that their sterling reputations reflected the selection of students rather than their ability to generate value-added test-score gains. Nyangweso et al. (2019) findings showed that value addition in public secondary schools in Kenya was not based on secondary school characteristics. The study concluded that irrespective of the score at KCPE and the category of public secondary school a student is admitted after KCPE, a student can add academic value. Research examining the performance of upgraded national schools in western Kenya is inadequate. Therefore, this paper examines the academic performance of eight upgraded extra county schools to national status in Western Kenya counties of Busia, Bungoma, Kakamega and Vihiga.

\section{MATERIALS AND METHODS}

The study was conducted in four Western Kenya Counties of Vihiga, Bungoma, Kakamega and Busia. There are eight upgraded national schools with an estimated student population of 5,600 and 270 members of the teaching staff by the year 2019 . The study used a mixed-method research paradigm with a descriptive survey research design. The eight upgraded extra county schools to the national level were Lugulu Girls, Bunyore Girls, Friends School Kamusinga, Butula Boys, Kakamega Boys, Butere
Girls, Kolanya Girls and Chavakali Boys. The target population consisted of 8 principals and 295 teachers. The sample size involved 170 teachers and eight principals who were selected through systematic sampling and purposive sampling methods.

Questionnaires, interview schedules and document analysis were used to collect data. Quantitative data was coded, entered and analysed with the help of SPSS Version 23.0 computer software. Analysis of data was done using frequencies, percentages, means and standard deviation. One sample t-test was used to determine if there existed a significant difference in the academic performance of schools between the before they were upgraded to the period they were upgraded. Qualitative data was analysed using thematic content analysis.

\section{RESULTS AND DISCUSSIONS}

This study examined the academic performance of upgraded National Schools in Western Kenya by looking at the situation before and after the upgrade. Data was collected through questionnaires, interview schedules and document analysis. KCSE performance data collected from seven schools out of eight related to KCSE mean score. The outcomes are summarised in Table 1.

Table 1: Academic Performance of Upgraded National Schools between 2014-2018

\begin{tabular}{lllllllll}
\hline Schools & \multicolumn{4}{l}{ KCSE Mean score in Years } & & Average & Grade & $\begin{array}{l}\text { \% } \\
\text { change }\end{array}$ \\
\cline { 2 - 6 } & $\mathbf{2 0 1 4}$ & $\mathbf{2 0 1 5}$ & $\mathbf{2 0 1 6}$ & $\mathbf{2 0 1 7}$ & $\mathbf{2 0 1 8}$ & & & -17.5 \\
School A - Bungoma & 10.1 & 10.2 & 9.6 & 9.8 & 8.33 & 9.606 & B+ & -1.5 \\
School B - Vihiga & 7 & 9.781 & 5.287 & 6.227 & 6.195 & 6.898 & C+ & -11.5 \\
School C - Kakamega & 8.213 & 8.801 & 7.107 & 6.69 & 6.64 & 7.490 & B- & -19.2 \\
School D - Kakamega & 8.7 & 9.04 & 7.8 & 7.62 & 6.88 & 8.008 & B- & -20.9 \\
School E - Bungoma & 9.285 & 9.156 & 8.34 & 7.831 & 7.73 & 8.468 & B & -16.7 \\
School F - Busia & 7.93 & 8.907 & 5.67 & 5.92 & 6 & 6.885 & C+ & -24.3 \\
School G - Busia & & & & & & 0.000 & n/a & -0.0 \\
School H - Vihiga & 9.68 & 8.82 & 8.18 & 8.09 & 7.7 & 8.494 & B & -20.5 \\
Average & $\mathbf{8 . 7 0 1}$ & $\mathbf{9 . 2 4 4}$ & $\mathbf{7 . 4 2 6}$ & $\mathbf{7 . 4 5 4}$ & $\mathbf{7 . 0 6 7}$ & $\mathbf{7 . 9 7 8}$ & B- & $\mathbf{- 1 8 . 7}$ \\
\hline
\end{tabular}

The statistics show that in the year 2014, the average KCSE performance for the seven schools was 8.7, which rose to 9.2 in 2015 , slumped to 7.42 in the year 2016 and maintained the same score in the year $2017(M=7.45)$ but slumped to 7.06 in the year 2018. The data show that there has been a significant decrease in performance from the year 2014 by $18.6 \%$ for the seven schools. Analysis of individual KCSE performance by the upgraded national schools shows that School F recorded a big slump in performance by $24.3 \%$, followed by School D (20.9\%) and thirdly School H (20.5\%). 
Only School B performance change was marginal (11.5\%) among the upgraded secondary schools. Odanga (2019) indicated that in 2019 examinations, not a single student posted grade $\mathrm{A}$ in Butula for the last four years. Butula recorded six A- and a mean score of 6.7 points and this performance was worrying to stakeholders in education. The performance of students in KCSE over the 6 - year period is given in Figure 1.

Figure 1: Performance of Upgraded National Schools between 2014-2018



Figure 1 statistics show that the performance of students from the schools has dipped from 2015 to 2018.
The study also collected enrolment data of students in Form 1 over the same period, as shown in Table 2.

Table 2: Enrolment of Students in Form 1 in Upgraded National Schools from 2014-2019

\begin{tabular}{|c|c|c|c|c|c|c|c|c|}
\hline \multirow[t]{2}{*}{ Schools } & \multicolumn{6}{|c|}{ Enrolment of Students in Form I } & \multirow{2}{*}{$\begin{array}{l}\text { Diff } \\
(2014-2019)\end{array}$} & \multirow{2}{*}{$\begin{array}{l}\% \quad \text { change } \\
(2014-2019)\end{array}$} \\
\hline & 2014 & 2015 & 2016 & 2017 & 2018 & 2019 & & \\
\hline School A - Bungoma & & & 300 & 360 & 455 & 520 & & \\
\hline School B - Vihiga & 376 & 492 & 535 & 573 & 564 & 582 & 206 & 54.8 \\
\hline School C - Kakamega & 320 & 340 & 480 & 540 & 600 & 600 & 280 & 87.5 \\
\hline School D - Kakamega & 322 & 360 & 398 & 401 & 502 & 506 & 184 & 57.1 \\
\hline School E - Bungoma & & & 336 & & & 485 & 149 & 44.3 \\
\hline School F - Busia & 284 & 299 & 298 & 312 & 317 & 327 & 43 & 15.1 \\
\hline School G - Busia & 885 & 1025 & 1180 & 1241 & 1270 & 1247 & 362 & 40.9 \\
\hline School H - Vihiga & 360 & 390 & 460 & 490 & 420 & 424 & 64 & 17.8 \\
\hline Average & 425 & 484 & 527 & 593 & 612 & 596 & 171 & 40.4 \\
\hline
\end{tabular}

The results above show that because of the upgrading of extra county schools to national status, there was a significant increase in enrolment in the upgraded national schools to different levels from the year 2014 to date (2019). The institution that recorded an $87.5 \%$ increase in enrolment was
School C from the initial 320 to 600 students. The second institution that recorded the highest increase in enrolment $(57.1 \%)$ was School D from 322 to 506, whereas the third was School B from the initial 376 to 582 students showing a $54.8 \%$ increase. During the interview, the principal of one of the

29 | This work is licensed under a Creative Commons Attribution 4.0 International License. 
national schools in Busia County indicated that the school had a population of 1,200 students by the year 2019. He indicated that:

The population of students has increased, but the facilities have remained the same. The situation in our institution does not reflect its status as a National School.

This means that enrolment has increased over the years over the period and it can be graphically shown as shown in Figure 2.

Figure 2: Enrolment of Students in Form 1 in Upgraded National Schools from 2014-2019

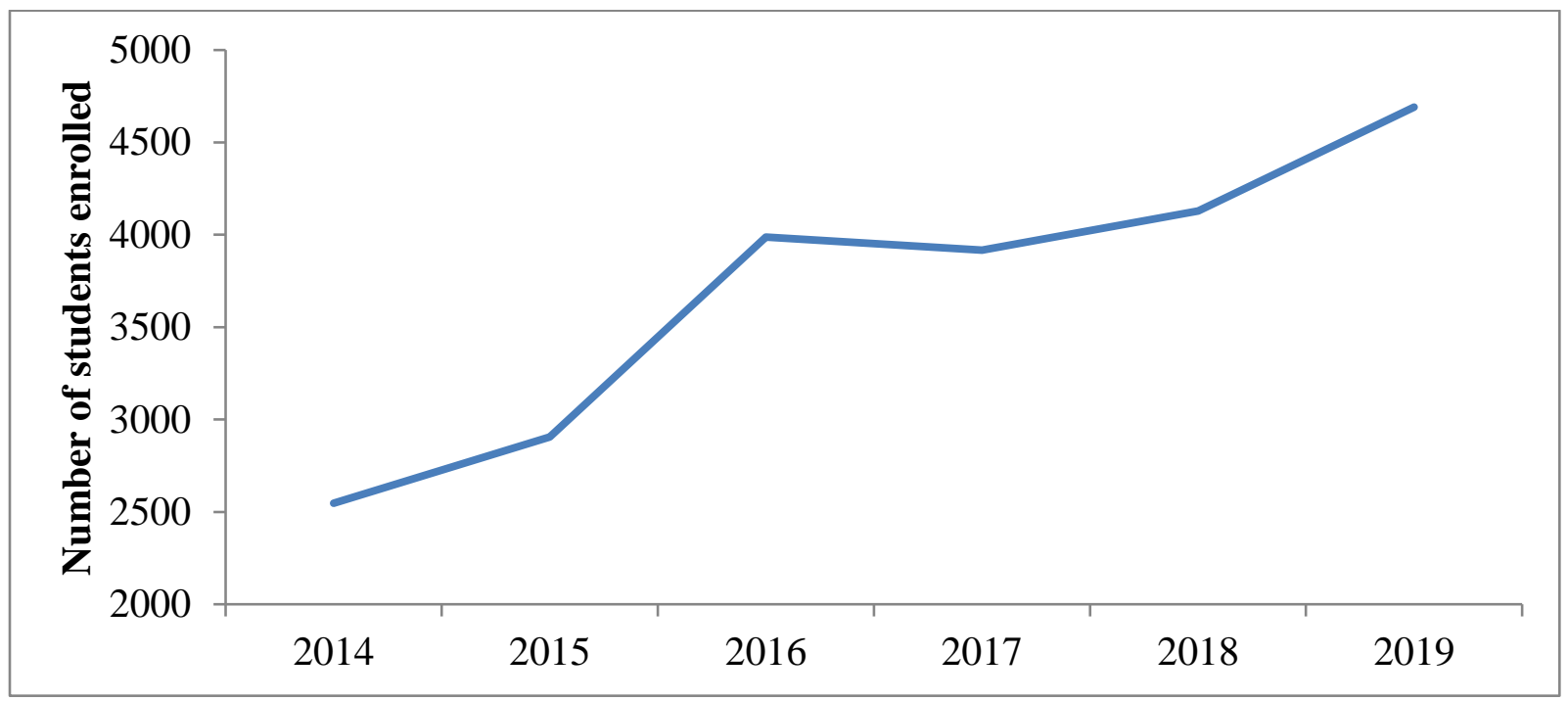

Average statistics show that the upgraded secondary schools in Western Kenya experienced a $40.4 \%$ increase in enrolment over the five-year period. This means that proper planning measures were expected to be put in place to address the compounding demands that came with increased enrolment in public secondary schools in the region.
From the document analysis, the study collected data on the student population from the selected upgraded National Schools from Form one to Form four over the same period. The results are as shown in Table 3.

Table 3: Students Population - Form 1 to Form Four (2014-2019)

\begin{tabular}{|c|c|c|c|c|c|c|c|c|}
\hline \multirow[t]{2}{*}{ Schools } & \multicolumn{6}{|c|}{ Students Population - Form 1 to Form Four } & \multirow{2}{*}{$\begin{array}{l}\text { Diff } \\
(2014-2019)\end{array}$} & \multirow{2}{*}{$\begin{array}{lr}\% & \text { change } \\
(2014 & -2019)\end{array}$} \\
\hline & 2014 & 2015 & 2016 & 2017 & 2018 & 2019 & & \\
\hline School A - Bungoma & & & & & & & 0 & 0 \\
\hline School B - Vihiga & 1589 & 1644 & 1800 & 1866 & 1870 & 1872 & 283 & 17.8 \\
\hline School C - Kakamega & 1562 & 1502 & 1820 & 1911 & 1962 & 1956 & 394 & 25.2 \\
\hline School D - Kakamega & 1602 & 1710 & 1810 & 1822 & 1899 & 1900 & 298 & 18.6 \\
\hline School E - Bungoma & 899 & 989 & 1041 & 1189 & 1172 & 1250 & 351 & 39.0 \\
\hline School F - Busia & 998 & 979 & 1012 & 1012 & 1109 & 1225 & 227 & 22.7 \\
\hline School G - Busia & & & & & & & 0 & 0 \\
\hline School H - Vihiga & 800 & 860 & 1137 & 1420 & 1600 & 1660 & 860 & 107.5 \\
\hline Total & 7450 & 7684 & 8620 & 9220 & 9612 & 9863 & 2413 & 32.4 \\
\hline
\end{tabular}

Results in Table 3 show that six schools student population by 2014 was 7,450 but rose significantly to 9,863 , representing a rise of $32.4 \%$ in the year 2019. The results show that despite enrolment of students, the four years showed a great increase in students' enrolment for some schools. For instance, School H students' population rose by more than $100 \%$ to record 1660 students from the initial 800

30 | This work is licensed under a Creative Commons Attribution 4.0 International License. 
population in the year 2014. The least student population recorded was for School C, which had 283 students more than the initial 1589 in the year 2014. The outcomes show that the schools therefore needed to have come up with proper planning strategies to meet the curriculum needs for the increased institutional capacity. The information on student population can be graphically shown in Figure 3 from all schools over the same period.

Figure 3: Students Population - Form 1 to Form Four (2014-2019)

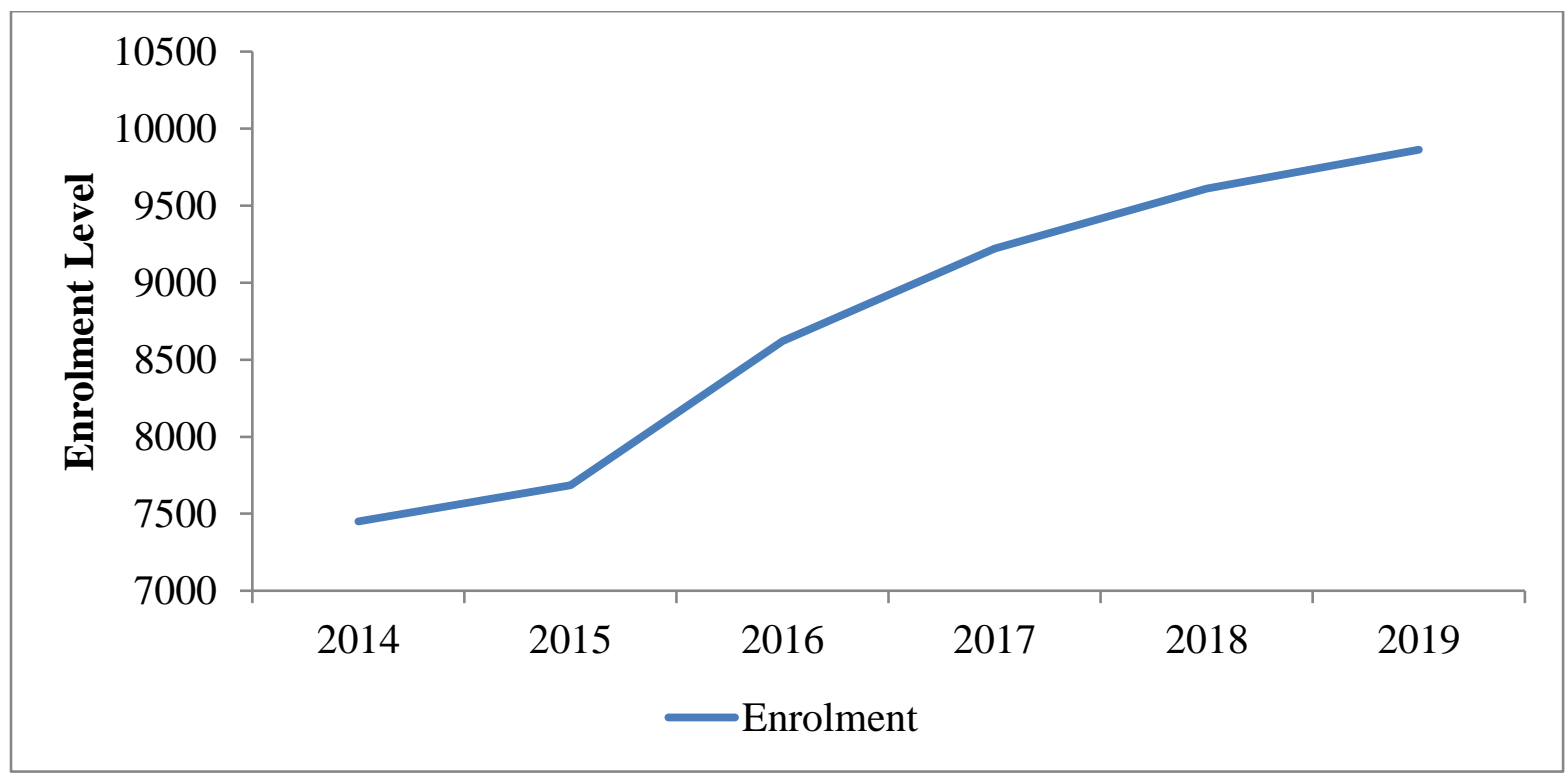

Further, the study requested the teachers to show the performance of their schools in various areas before and after the upgrading process using a Likert scale of five; Very high (5), high (4), moderate (3), low (2) and very low (1). The descriptive data are presented in Table 4 below.

Table 4: Performance of Upgraded National Schools (Before \& After)

\begin{tabular}{|c|c|c|c|c|c|c|}
\hline \multirow[t]{2}{*}{ Performance area } & \multirow[t]{2}{*}{$\mathbf{N}$} & \multicolumn{2}{|c|}{ Before upgrade } & \multicolumn{2}{|c|}{ After upgrade } & \multirow[t]{2}{*}{ Mean diff } \\
\hline & & Mean & Std. D & Mean & Std. D & \\
\hline Student enrolment & 158 & 3.5190 & .84251 & 3.7595 & 2.56242 & -0.2405 \\
\hline Student retention & 158 & 3.7595 & .75232 & 4.1139 & .98378 & -0.3544 \\
\hline Student completion rate & 158 & 3.8734 & .64575 & 3.7975 & .97588 & 0.0759 \\
\hline Syllabus coverage & 158 & 3.5823 & .77554 & 3.4937 & .98231 & 0.0886 \\
\hline KCSE performance & 156 & 3.6795 & .90152 & 2.8608 & .96742 & 0.8187 \\
\hline Performance in extracurricular activities & 158 & 4.0759 & 1.06803 & 3.6538 & 1.14528 & 0.4221 \\
\hline Teacher retention & 158 & 2.9747 & 1.05848 & 3.0127 & 2.60814 & -0.038 \\
\hline Quality education provision & 158 & 3.5949 & 1.04081 & 3.6076 & 2.62238 & -0.0127 \\
\hline Valid N (Listwise) & 156 & 3.6324 & 0.8856 & 3.5374 & 1.6060 & 0.0950 \\
\hline
\end{tabular}

The results in Table 4 show that student enrolment had increased after the upgrade of the eight schools to national status through the mean difference obtained (Mean difference $=-0.24$ ). This shows that most schools did record an increase in the enrolment of students after they were upgraded. This could be because the government through MOE was posting more teachers in those schools. Observation by the study showed that in the eight schools visited, the students' population exceeded 1,000.

Additionally, in terms of retention, there was an increase in retention rate, as seen where the mean changed from 3.75 to 4.1 . This explains the positive

31 This work is licensed under a Creative Commons Attribution 4.0 International License. 
contribution of the transformation of these schools as more students are seen to be retained in schools. Nevertheless, the completion rate shows a marginal decrease among students by 0.0759 . This can be seen with the case for syllabus coverage which the majority of teachers said that it changed from high $(M=3.58)$ to low $(M=3.49)$. In terms of their KCSE performance, there was a lowering in performance from 3.67 to 3.49. This show that there existed a reduction in KCSE means score for institutions that were upgraded. This agrees with findings of research conducted by Livumbaze and Achoka (2017) who found that students' academic achievement in public secondary schools in the Hamisi Sub-County is very low. Nevertheless, Odanga (2019) reported that one of the former students of Butula said that as an alumnus of this school, they were making relevant efforts from various fronts to ensure the school begins to post good performance in KCSE.

The same drop was in co-curricular activities performance was observed from a mean of 4.07 to 3.6, which is quite high. This show that the newly upgraded schools reduced emphasis on sporting activities while focusing on other activities. When looking at retention, this research paints a different picture where it is seen that majority of teachers were retained (from 2.97 to 3.01). This show that the majority of teachers remained in their schools despite the challenges that they encountered after they were upgraded from extra county to national level. Lastly, in terms of teachers rating of provision of quality education, the statistics showed a significant increase from a mean of 3.59 to 3.60. This show that upgrading of National Schools came with minimal improvement in quality education provision in schools.

Average data from the two periods (before and after) show that the institutional performance changed from a mean of 3.66 from the teachers' perspective to 3.50 . This shows that there was a significant shakeup by schools because of the eight schools being upgraded to national status. To establish if there existed a significant difference between KCSE performances before the institutions were upgraded to national status and the situation after they were upgraded, a one-sample t-test was computed at a $95 \%$ significant level. The findings are as shown in Table 5.

Table 5: One-Sample Statistics

\begin{tabular}{lllll}
\hline & N & Mean & Std. Deviation & Std. Error Mean \\
\hline Performance before & 158 & 3.6592 & .60025 & .04775 \\
Performance after & 158 & 3.5037 & .73313 & .05832 \\
\hline
\end{tabular}

Table 5 show that the performance before the upgrade was 3.6, but this dropped to 3.50 after they

were upgraded. Table 6 shows whether the difference was significant using a test value of 2.5.

Table 6: One-Sample Test

\begin{tabular}{|c|c|c|c|c|c|c|}
\hline & \multicolumn{6}{|c|}{ Test Value $=2.5$} \\
\hline & \multirow[t]{2}{*}{$\mathbf{t}$} & \multirow[t]{2}{*}{ df } & \multirow[t]{2}{*}{ Sig. (2- tailed) } & \multirow[t]{2}{*}{ Mean Diff } & \multicolumn{2}{|c|}{$\begin{array}{l}\text { 95\% Confidence Interval } \\
\text { of the Difference }\end{array}$} \\
\hline & & & & & Lower & Upper \\
\hline Performance before & 24.274 & 157 & .000 & 1.15918 & 1.0649 & 1.2535 \\
\hline Performance after & 17.208 & 157 & .000 & 1.00367 & .8885 & 1.1189 \\
\hline
\end{tabular}

The research findings (Table 6) show that there existed a significant difference $(\mathrm{p}<0.05)$ in upgraded National Schools performance before and after they were upgraded. The research concludes that there exists a significant difference in performance before and after upgrading of the schools to national status in Western Kenya. This implies that there was a change in institutional performance after the eight schools in the four Counties of Western regions were upgraded to national status. That is there was a drop in performance in academics 
Further, teachers were asked to indicate the average enrolment per class before and after their school were upgraded from Extra County to national status. The results are shown in Table 7.

Table 7: Class Enrolment Before and After Upgrade

\begin{tabular}{lllll}
\hline Range & Before & & After & \\
\cline { 2 - 5 } & Frequency & Percent & Frequency & Percent \\
\hline $2-19$ & 7 & 4.4 & 0 & 0.0 \\
$20-49$ & 18 & 11.4 & 4 & 2.5 \\
$50-99$ & 33 & 20.9 & 42 & 26.6 \\
$100-199$ & 14 & 8.9 & 14 & 8.9 \\
200 and above & 86 & 54.4 & 98 & 62.0 \\
Total & $\mathbf{1 5 8}$ & $\mathbf{1 0 0 . 0}$ & $\mathbf{1 5 8}$ & $\mathbf{1 0 0 . 0}$ \\
\hline
\end{tabular}

The result in Table 7 shows that the majority of teachers $(86,54.4 \%)$ said that their average class size (depending on the number of streams) was 200 and above before upgrading and this number increased after enrolment to $98(62.0 \%)$. In addition, for classrooms that had 2-19 students (4.4\%), they ceased to exist. The above data show that there has been a significant increase in class size after the schools were upgraded to national status in the Western region of Kenya. Therefore, the results show that the upgraded National Schools in this region, due to pressure experienced in varied performances in terms of academic and nonacademic areas.

\section{CONCLUSIONS AND RECOMMENDATIONS}

Performance data collected shows that there was marginal from the time before they were upgraded to the current through a marginal mean of 3.66 before to 3.50 now. This showed that in some schools, the upgrading status led to the increase in enrolment of students, low completion rate of students as some are transferred to other schools or drop out, reduced performance in KCSE and cocurricular activities. The performance areas that improved as a result of upgrading was on student retention, teacher retention and quality education provision. The computed t-test statistics show that the difference was significant $(\mathrm{p}<0.05)$, which resulted in the conclusion that there existed a significant difference in KCSE mean score before and after the schools were upgraded to national status in Western Kenya. The study recommends that the Teachers Service Commission should deploy more teachers to address the staffing shortage in these upgraded schools in order to ensure quality education is provided. The upgraded national schools' board of management need to be proactive in ensuring that the right resources and facilities are provided in schools to ensure effective condition for learning. The Ministry of Education needs to support schools to upgrade their infrastructure to ensure that the learning conditions are conducive and favourable for learning.

\section{REFERENCES}

Biama, T. M. (2014). Factors Influencing Academic Performance of Public Secondary Schools in Matungulu District, Machakos County, Kenya. Post Graduate Diploma Project, University of Nairobi.

Gitogo, I. G. (2018). Perceptions and trends in academic performance of secondary school students with a public and private primary schools background: a case of Alliance national secondary schools, Kenya (Doctoral dissertation, Moi University).

Kithela, S. M. (2016). Relationship among school type and secondary school students' self-esteem, academic achievement and career aspirations in Nairobi County, Kenya (Doctoral dissertation, Kenyatta University).

Livumbaze, A. G. \& Achoka, S.K. J. (2017). Analysing the Effect of Teaching/Learning Resources on Students' Academic Achievement in Public Secondary Schools, Hamisi SubCounty, Kenya. European Journal of Education Studies, 3(1), 361 - 376. 
Lucas, A. M., \& Mbiti, I. M. (2014). Effects of school quality on student achievement: Discontinuity evidence from Kenya. American Economic Journal: Applied Economics, 6(3), 234-63.

Ngoko, A. (2019, Feb 6). Kolanya Girls High School seeks help towards infrastructure. https://www.standardmedia.co.ke/Western/artic le/2001313294/school-seeks-help-towardsinfrastructure

Nyangweso, J. O., Maiyo, J. K., \& Kati, R. (2019). Effect of Secondary School Categorization on Value Addition in Public Secondary Schools Students in Kenya. Journal of Education and Practice, 10(33), 70 - 75.

Odanga, I. $\left(2019,30^{\text {th }}\right.$ Dec). Team to probe why schools failed to record $A$ in KCSE. https://www.standardmedia.co.ke/Western/artic le/2001354746/team-formed-to-probeperformance-in-exams

Odumbe, G. A., Simatwa, E. M., \& Ayodo, T. M. O. (2015). Factors Influencing Student Academic Performance in Day Secondary Schools in Kenya; A case study of Migori Sub County. Greener Journal of Educational Research, 5(3), 078-097.

Republic of Kenya (2010). The Constitution of Kenya. Nairobi: The National Council of Law.

Republic of Kenya (2011). A Policy Framework for Education. Aligning Education and Training to the Constitution of Kenya (2010) and Kenya Vision 2030 and Beyond. Nairobi Government Printer.

Sidi, R. R., Kindiki, J., \& Ongeti, K. (2020). Entry marks and KCSE performance in high and low performing schools in Mombasa County. International Academic Journal of Education \& Literature, 1(6), 240-245.

Siringi, S. (2014, $5^{\text {th }}$ March). Some national schools performed so poorly; they were trounced by district ones. Available online a https://nation.af rica/kenya/news/shame- of- national- schools- $\mathrm{s}$ tuck-in-d-leaue-957680
Wekesa, V. \& Kipkoech, L. (2021). Infrastructural resource planning dynamics and performance of upgraded extra county schools to national status in western Kenya counties. European Journal of Education Studies, 8(2), 399 - 410.

Wekesa, V., \& Kitainge, K. (2020). Human resource planning dynamics and academic performance of upgraded national schools in Western Kenya Counties. European Journal of Education Studies, 7(7), 376 - 391.

Wekesa, V., Kipkoech, L., \& Okemwa, P. (2021). Financial Resource Planning Dynamics and Performance of Upgraded Extra-County Schools to National Status in Western Kenya Counties. East African Journal of Interdisciplinary Studies, 3(1), 27-39.

34 | This work is licensed under a Creative Commons Attribution 4.0 International License. 